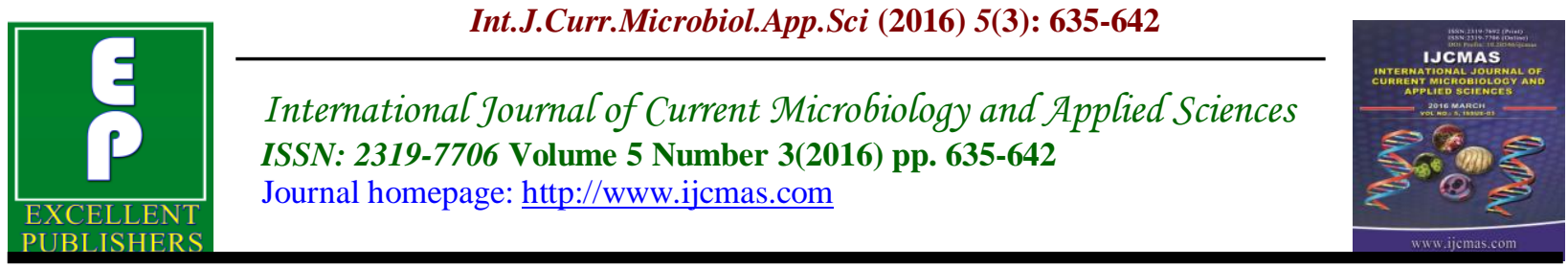

Original Research Article

http://dx.doi.org/10.20546/ijcmas.2016.503.074

\title{
In Vitro Shoot Proliferation from Excised Shoot Tip and Nodal Segment of Anacardium occidentale $\mathbf{L}$.
}

\author{
S.L. Sija ${ }^{1 *}$, V.P. Potty ${ }^{2}$ and P.S. Santhoshlal ${ }^{1}$ \\ ${ }^{1}$ Research Department of Botany \& Biotechnology, Sree Narayana College, \\ Kollam-691 001, Kerala, India \\ ${ }^{2}$ The CEPCI Laboratory \& Technical Division, Cashew Bhavan, kollam-691 001, Kerala, India \\ *Corresponding author
}

A B S T R A C T

Keywords

Anacardium occidentale L., Plant growth regulators, In vitro multiplication.

Article Info

Accepted:

20 February 2016

Available Online:

10, March 2016
An efficient in vitro shoot proliferation protocol was established through excised shoot tip and nodal segment of Anacardium occidentale. The effect of different growth regulators alone or in combination on multiple shoot production from different explants of A.occcidentale was studied. Shoot proliferation were obtained from excised shoot tips and nodal segments from in vitro grown seedlings of cashew were cultured on MS medium supplemented with NAA alone or in combination with BAP and Kinetin. Maximum number of shoots (3-5 per explants) was obtained from excised nodal segment.

\section{Introduction}

Cashew (A.occidentale L.) is medicinally and economically important tropical horticultural crop, a member of the family Anacardiaceae. It is indigenous to north eastern Brazil (Azam-Ali and Judge, 2000), which is now widely grown in other tropical countries like India and is a multi-purpose plant (Togan 1977). Cashew nut and liquid from nut shell (CNSL) are the two most important parts have lot of applications in medical and industrial field (Rajesh et al., 2009).
According to Ammirato et al., (1984) in vitro micropropagation has been successful for several horticultural fruit species. In in vitro studies, cashew has been seen to be more recalcitrant (Mantell et al., 1998). In in vitro clonal propagation, herbaceous plants can be propagated by using mature or immature tissue whereas it is too difficult in the case of perennial plants (Sumita and Sudripta 2005). Cashew nut was found difficult to propagate in vitro from mature plant tissues (shoot apices or nodal explants) 
due to recalcitrant nature, microbial contaminations and high phenolic exudation. Though micropropagation in cashew has been experimented using explants of both juvenile (seedling) and mature tree origin, favorable regeneration has been accomplished only in the explants of juvenile origin (Thimmappaiah and Shirly 1999). Philip (1984) reported the direct plantlet regeneration from mature nut cultures. Attempts to develop a micropropagation protocol for cashew, a complete regeneration system has obtained through organogenesis (Philip 1984; Thimmappaiah et al., 2002). The present study was aimed at raising both regeneration efficiency and the multiple shoot production for mass propagation of $A$. occidentale.

\section{Materials and Methods}

\section{Plant Materials}

Juvenile twigs were collected from mature trees grown at Kerala State Cashew Development Corporation, Mundakkal, Kollam, Kerala, India. Shoot tips and nodal explants were treated with a fungicide (Bavistin $1 \mathrm{~g} / \mathrm{l}$ ) for $1 \mathrm{~h}$ followed by sterilization with $0.1 \% \mathrm{HgCl}_{2}$ for $10 \mathrm{~min}$, and 5 washes with sterile distilled water. The explants were then cultured on MS (Murashige and skoog 1962) medium enhanced with different concentrations of the growth regulators NAA, BAP and Kinetin independently or in combinations. The $\mathrm{pH}$ of the medium was adjusted to 5.8 before autoclaving. The media were sterilized by autoclaving at $121^{\circ} \mathrm{C}$ for 15 min. The cultures were incubated at $25 \pm 2^{0}$ $\mathrm{C}$ under dark.

Mature cashew seeds were collected from Kerala State Cashew Development Corporation, Mundakkal, Kollam, Kerala, India. Seeds were efficiently washed in sterile distilled water consist of a pinch of detergent. Sterilization was carried out in $70 \%$ ethanol (10 $\mathrm{min})$ followed by agitation in $0.1 \% \mathrm{HgCl}_{2}(20 \mathrm{~min})$. Later they were rinse thrice with sterile distilled water and germinated under dark condition in culture bottles.

\section{In vitro and Ex vitro Germination of Seeds}

The MS basal media were tested for their effectiveness in promoting the in vitro germination of cashew seeds. The basal media tested for seed germination were fortified with $2 \%$ sucrose without plant growth regulators (PGRs). In order to achieve a high germination rate, MS medium was then supplemented with various PGRs at fixed concentrations (2-5 $\mathrm{mg} / \mathrm{l})$ individually. In all cases, MS medium was altered by adding $2 \mathrm{~g} / \mathrm{l}$ activated charcoal. All media were solidified with $0.8 \%$ agar and adjusted to $\mathrm{p}^{\mathrm{H}} 5.8$ before autoclaving.

Sterile media were allocated into culture bottles. Surface-sterilized seeds were inoculated to culture bottles with media under dark for germination and maintained. At the end of 2 weeks, seed germination was observed and germination percentages were determined by dividing the number of germinated seeds by the total number of viable seeds in the same media.

Seeds were planted on plastic trays, containing washed and sterilized sand as substrate in laboratory conditions to obtain ex vitro growing plantlets for further experiments.

\section{In vitro Shoot Proliferation from Shoot Tip and Nodal Segment}

Detopped shoots from ex vitro germinated seedlings were defoliated and segmented into nodal and shoot tip cuttings for 
culturing. The explants were then cultured on MS medium supplemented with various concentrations of the growth regulators NAA, BAP and Kinetin separately or in combinations. The $\mathrm{pH}$ of the medium was modified to 5.8 before autoclaving. The media were sterilized by autoclaving at $121^{\circ} \mathrm{C}$ for $15 \mathrm{~min}$. The cultures were incubated at $25 \pm 2{ }^{\circ} \mathrm{C}$ under dark.

\section{Statistical Analysis}

Data were expressed as means and standard deviation (SD) of three replicate determinations. All statistical analyses were carried out using a SPSS (Chicago, IL) statistical software package (SPSS for Windows, ver. 17, 2008). To determine whether there were any differences among the means, one way analysis (ANOVA) and the Duncans New Multiple range test were applied to the result at 0.05 level of significance $(\mathrm{p}<0.05)$

\section{Results and Discussion}

Juvenile twigs procured from mature trees were inadequate as explant source. Shoot tip and nodes had only a $2 \%$ and $15 \%$ survival, respectively, after the decontamination procedures necessary for field grown twigs. The few explants that survived sterilization turned brown and died within a week. Hence seedlings germinated ex vitro were the source for explant material in the following experiments.

\section{In vitro and $E x$ vitro Germination of Seeds}

Results of the present study indicated that existence of growth regulators significantly affected in vitro seed germination. It was observed that the auxin 2,4-D alone was poor in inducing seed germination. Combination of 2,4-D, BAP and NAA was found to be most effective that showed 72.2 $\pm 0.83 \%$ germination in 8days (Table 1 and Figure 1) and it was found to be significantly different $(\mathrm{p}<0.05)$ as correlated with the other hormonal concentrations. Whereas the seed germination percentage was only $27.83 \pm$ $1.16 \%$ in MS media without growth regulators. Earlier researchers have worked on in vitro seed germination of A.occidentale on MS medium (Thimmappaiah and Shirly 1999; Sudripta et al., 1996). The ex vitro germination of seeds started after 10 days and it showed $90 \%$ of germination. Microshoots and leaves sprouted from decapitated seedling were used as the explants for the present study (Figure 2).

\section{In vitro Shoot Proliferation through Shoot Tip and Nodal Segment}

In the present study cashew explants were tested for in vitro multiplication.Excised shoot tips inoculated on basal MS medium failed to show shoot proliferation. Whereas excised shoot tips inoculated on MS medium supplemented with either NAA $(2-5 \mathrm{mg} / \mathrm{l})$ or BAP (2-5 mg/l) alone also produced shoot proliferation. But the highest shoot proliferation efficiency $(57.2 \pm 0.14 \%)$ was in the presence of NAA ( $5 \mathrm{mg} / \mathrm{l}), \mathrm{BAP}$ (3 $\mathrm{mg} / \mathrm{l})$ and Kinetin $(1 \mathrm{mg} / \mathrm{l})$ (Table 2 and Figure.3). This concentration and combination for shoot proliferation from excised shoot tip were not seems to be reported earlier and it was in contrast with the findings of earlier study where maximum percentage of shoot proliferation (2 buds/ explant) from shoot tip were observed on MS medium (Sudripta et al., 1996).

Nodal segments inoculated on MS basal medium showed 3-5 shoots per culture. There was no induction of multiple shoot on MS medium without growth regulators. 
Table.1 In Vitro Germinating Cashew Seeds on MS Medium

\begin{tabular}{|c|c|c|c|c|c|}
\hline \multirow{2}{*}{ SI.No } & \multicolumn{3}{|c|}{ Growth hormones (mg/l) } & Germination & \\
\cline { 2 - 5 } & $2,4-\mathrm{D}$ & BAP & NAA & period (days) & Seed germination (\%) \\
\hline 1 & 0 & 0 & 0 & 9 & $27.83 \pm 1.16 \mathrm{a}$ \\
2 & 2 & - & - & 8 & $39.2 \pm 1.58 \mathrm{bc}$ \\
3 & 2.5 & - & - & 10 & $46.4 \pm 1.14 \mathrm{e}$ \\
4 & 3 & - & - & 9 & $35.6 \pm 1.75 \mathrm{~b}$ \\
5 & 3.5 & - & - & 7 & $43.5 \pm 1.22 \mathrm{~d}$ \\
6 & 5 & - & - & 6 & $54.3 \pm 1.03 \mathrm{f}$ \\
7 & 2.5 & 2 & 1 & 9 & $55.6 \pm 1.14 \mathrm{f}$ \\
8 & 3 & 2 & 1 & 12 & $63.8 \pm 0.83 \mathrm{~h}$ \\
9 & 3 & 2.5 & 1 & 10 & $47.6 \pm 1.14 \mathrm{e}$ \\
10 & 3 & 3 & 1 & 12 & $68.2 \pm 0.83 \mathrm{i}$ \\
11 & 5 & 2 & 1 & 7 & $56.4 \pm 1.81 \mathrm{~g}$ \\
12 & 5 & 2.5 & 1 & 8 & $72.2 \pm 0.83 \mathrm{j}$ \\
13 & 5 & 3 & 1 & 11 & $58.2 \pm 0.83 \mathrm{~g}$ \\
14 & 5 & 3.5 & 1 & 12 & $55.1 \pm 0.89 \mathrm{f}$ \\
\hline
\end{tabular}

For each treatment the means within the column by different letters are significantly different at $\mathrm{P}<0.05$. Each value is expressed as the means $\pm \mathrm{SD}$

Table.2 Effect of Various Concentrations of Plant Growth Regulators on In Vitro Shoot Proliferation from Shoot Tip Explants of A.occidentale After Four Weeks of Culture

\begin{tabular}{|c|c|c|c|c|}
\hline \multirow{2}{*}{ SI.No } & \multicolumn{3}{|c|}{ Growth hormones (mg/l) } & \multirow{2}{*}{$\begin{array}{c}\text { of shoot formation of } \\
\text { excised shoot tip }\end{array}$} \\
\cline { 2 - 4 } & NAA & BAP & KINETIN & 0 \\
2 & 0 & 0 & 0 & $16.4 \pm 1.14 \mathrm{a}$ \\
3 & 2 & - & - & $36.8 \pm 1.30 \mathrm{~d}$ \\
4 & 2.5 & - & - & $44.2 \pm 1.30 \mathrm{e}$ \\
5 & 3 & - & - & $16.4 \pm .89 \mathrm{a}$ \\
6 & 3.5 & - & - & $25.2 \pm 1.30 \mathrm{~b}$ \\
7 & 5 & - & - & $44.8 \pm 1.14 \mathrm{e}$ \\
8 & - & 2 & - & $16.4 \pm 1.30 \mathrm{a}$ \\
9 & - & 2.5 & - & $25.2 \pm 1.30 \mathrm{~b}$ \\
10 & - & 3 & - & $53.2 \pm .70 \mathrm{~g}$ \\
11 & - & 3.5 & - & $24.0 \pm .83 \mathrm{~b}$ \\
12 & - & 5 & - & $53.2 \pm 1.30 \mathrm{~g}$ \\
13 & 2 & 2 & 1 & $33.2 \pm 1.14 \mathrm{c}$ \\
14 & 2.5 & 3 & 1 & $36.4 \pm .83 \mathrm{~d}$ \\
15 & 5 & 2.5 & 1 & $57.2 \pm 0.14 \mathrm{~h}$ \\
16 & 5 & 3 & 1 & $47.2 \pm .83 \mathrm{f}$ \\
\hline
\end{tabular}

For each treatment the means within the column by different letters are significantly different at $\mathrm{P}<0.05$. Each value is expressed as the means $\pm \mathrm{SD}$ 
Table.3 Effect of Various Concentrations of Plant Growth Regulators on In Vitro Shoot Proliferation from Nodal Explants of A.occidentale after Four Weeks of Culture

\begin{tabular}{|c|c|c|c|c|}
\hline \multirow{2}{*}{ SI.No } & \multicolumn{3}{|c|}{ Growth hormones $(\mathrm{mg} / \mathrm{l})$} & \multirow{2}{*}{$\begin{array}{c}\text { \% of shoot formation of } \\
\text { excised nodal segment }\end{array}$} \\
\cline { 2 - 4 } & NAA & BAP & KINETIN & 0 \\
2 & 0 & 0 & 0 & $17.5 \pm 1.04 \mathrm{~b}$ \\
3 & 2 & - & - & $34.33 \pm 1.21 \mathrm{e}$ \\
4 & 2.5 & - & - & $42.28 \pm 1.60 \mathrm{~g}$ \\
5 & 3 & - & - & $24.83 \pm 0.75 \mathrm{c}$ \\
6 & 3.5 & - & - & $46.66 \pm 1.36 \mathrm{~h}$ \\
7 & 5 & - & - & $43.71 \pm 1.11 \mathrm{~g}$ \\
8 & - & 2 & - & $47.71 \pm 1.11 \mathrm{~h}$ \\
9 & - & 2.5 & - & $51.33 \pm 1.21 \mathrm{i}$ \\
10 & - & 3 & - & $53.33 \pm 0.81 \mathrm{j}$ \\
11 & - & 3.5 & - & $24.85 \pm 0.89 \mathrm{c}$ \\
12 & - & 5 & - & $47.66 \pm 0.81 \mathrm{~h}$ \\
13 & 2 & 2 & 1 & $15.28 \pm 1.11 \mathrm{a}$ \\
14 & 2.5 & 3 & 1 & $37.8 \pm 0.83 \mathrm{f}$ \\
15 & 5 & 2.5 & 1 & $64.2 \pm 1.30 \mathrm{k}$ \\
16 & 5 & 3 & 1 & $28.28 \pm 1.11 \mathrm{~d}$ \\
\hline
\end{tabular}

For each treatment the means within the column by different letters are significantly different at $\mathrm{P}<0.05$. Each value is expressed as the means $\pm \mathrm{SD}$

Figure.1(a-e) Different Stages of In Vitro Germination of Cashew Seeds on MS Medium

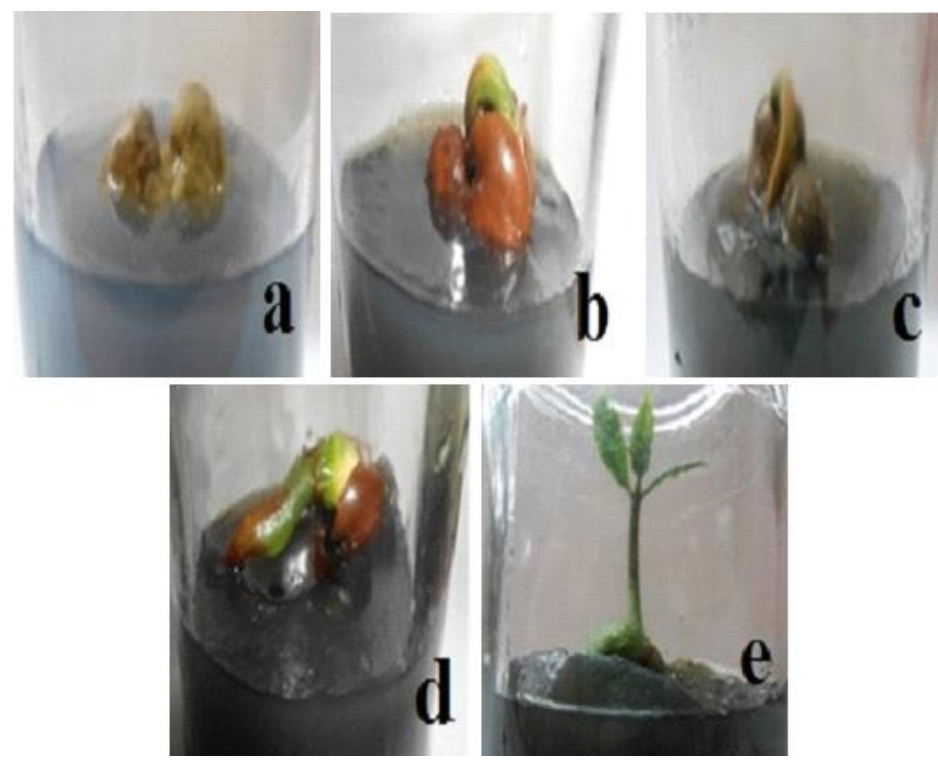


Figure.2 Ex Vitro Germination of Cashew Seeds
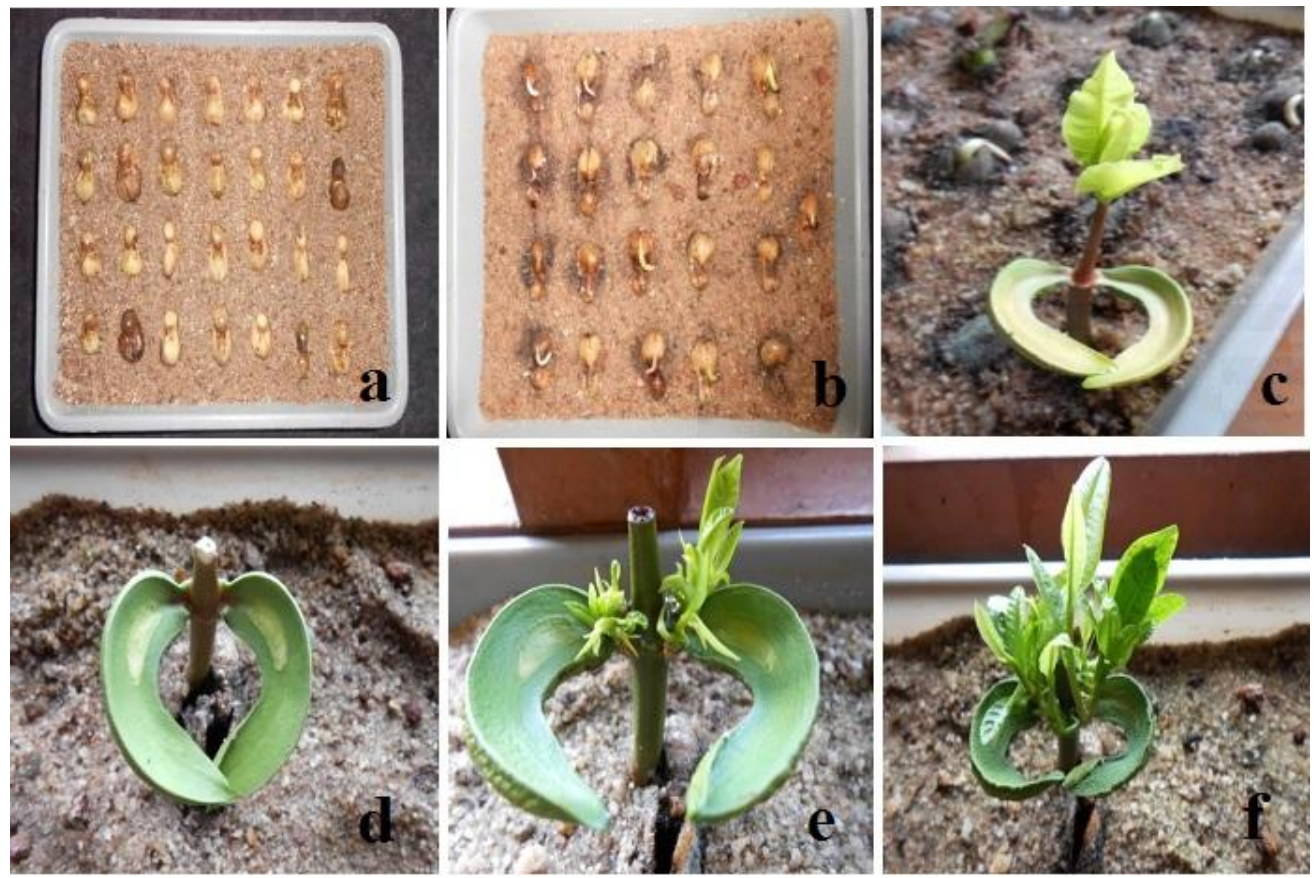

Figure.3 (a-d) In Vitro Shoot Proliferation from Shoot Tip Explants of A.occidentale
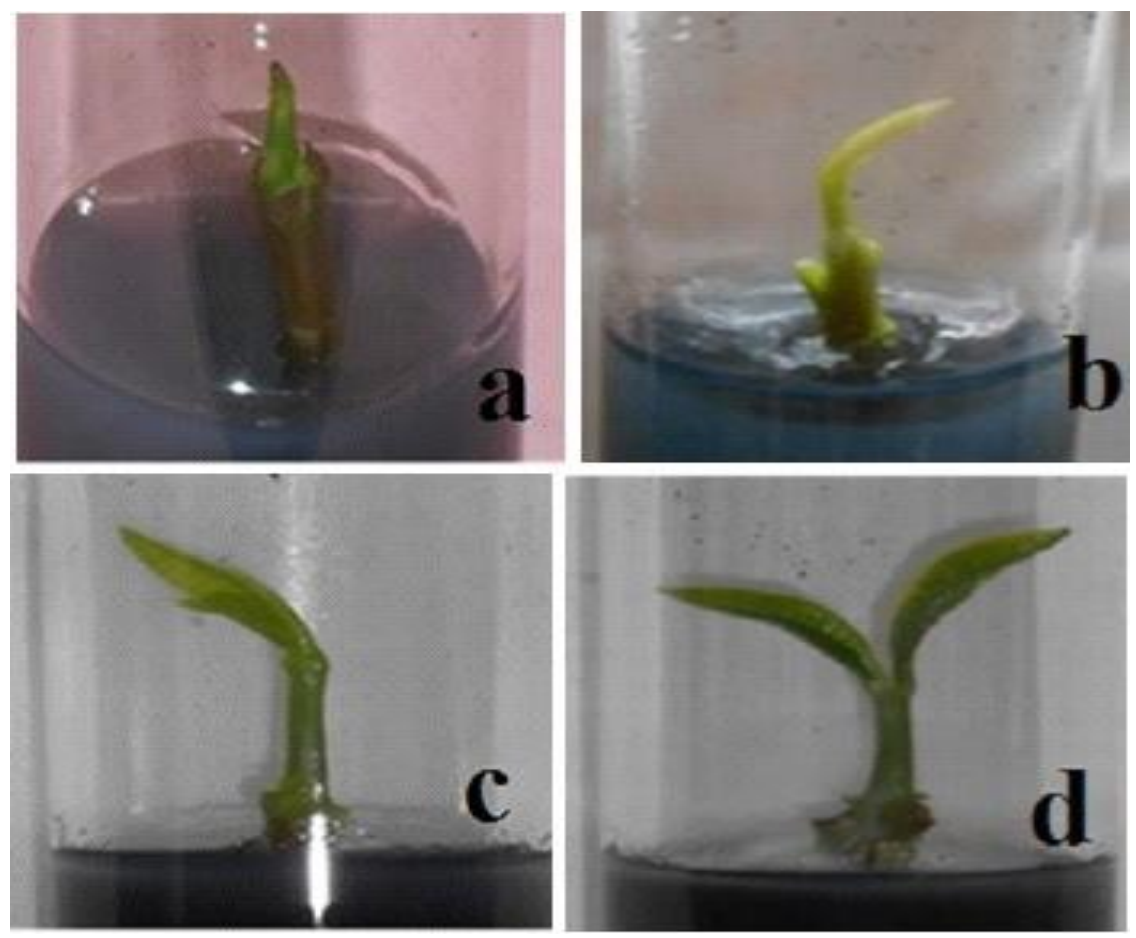
Figure.4(a-e) In Vitro Shoot Proliferation from Nodal Explants of A.occidentale

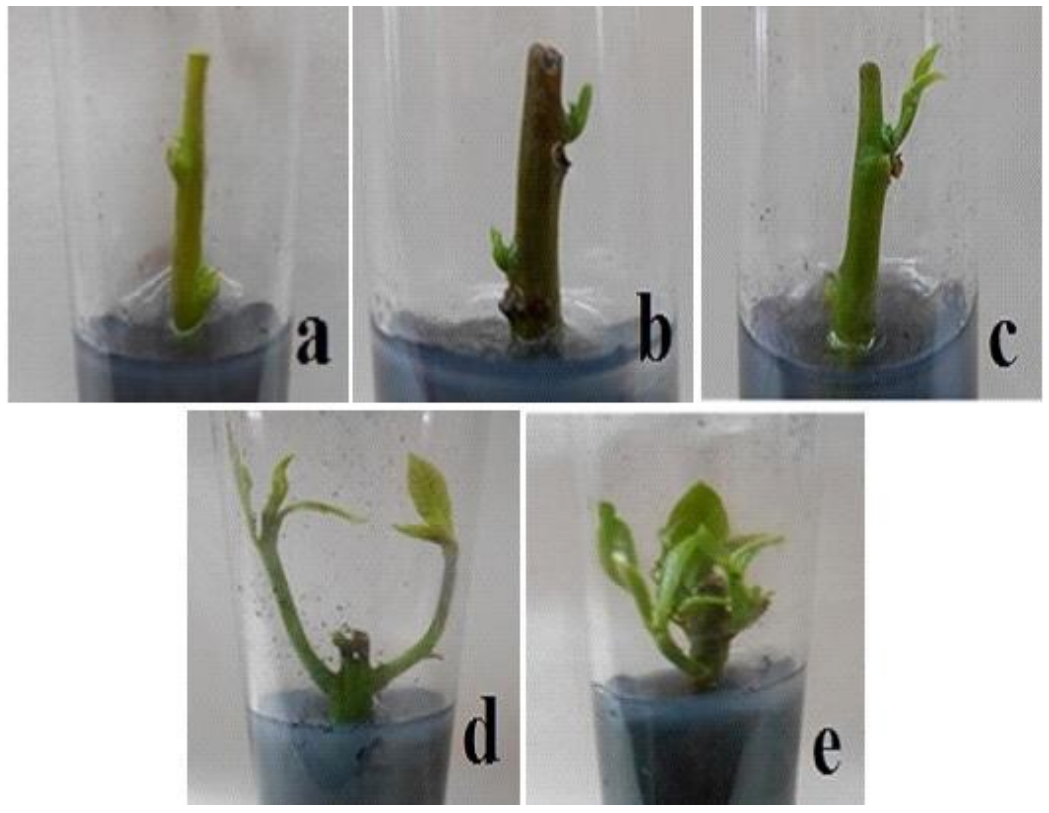

MS medium supplemented with either NAA $(2-5 \mathrm{mg} / \mathrm{l})$ or BAP $(2-5 \mathrm{mg} / \mathrm{l})$, alone showed alteration in the induction of multiple shoots which ranged between 17.5 to $46.66 \%$ in the case of NAA and 24.85 to $53.33 \%$ in the case of BAP alone. The highest percent of shoot proliferation $(64.2 \pm 1.30 \%)$ was obtained on MS medium supplemented with NAA (5 mg/l) and BAP (3 mg/l) and Kinetin $(1 \mathrm{mg} / \mathrm{l})$ (Table 3 and Figure.4). It was significantly different $(\mathrm{p}<0.05)$ as compared with other hormonal concentrations. This concentration and combination for multiple shoot induction from nodal segment were not seems to be reported earlier. Sudripta et al., (1996) also reported the role of cytokinins (BAP, Kinetin and Zeatin) in efficient regeneration of cotyledonary nodal explants of A.occidentale when cultured on MS medium.

\section{Acknowledgement}

The authors are thankful to the PG and Research Department of Botany \& Biotechnology, Sree Narayana College,
Kollam - 691 001, Kerala for providing the laboratory facilities to carry out the present work and also Kerala University for financial support.

\section{References}

Ammirato, P.V., 1984. Hand book of Plant Cell Culture. In. Crop species. (Eds.) Evans, D.A, Sharp, W.R, and Yamada, Y. Macmillan, New York. pp-327-355.

Azam-Ali S, JudgeE (2000).The global cashew industry-opportunities for small-scale processors. In: Proceedings of the international workshop on cashew production and processing-Cashing in on Cashew. pp. 1-10. Marawila: Sri Lanka.

Mantell, S.H., Boggett, B., Bessa, A.M .S., Lemos, E. E. P., and Abdelhad, A. R., Micropropagation and micrografting methods suitable for safe international transfer of cashew, in Proceedings of International Cashew and Coconut Conference, 
1997 ( Dar Es Salaam) 1998, 95-107. Murashige, T., and Skoog, F., 1962. A revised medium for rapid growth and bioassays with tobacco tissue cultures. Physiol. Plant.15: 473- 497.

Philip, V. J., 1984. In vitro Organogenesis and Plantlet Formation in Cashew (Anacardium occidentale L.).Annals of Botany.54(1):149-152.

Rajesh, K.V., Sumathi, C.S., Balasubramanian, V., and Ramesh, N., 2009.Elementary Chemical Profiling and Antifungal Properties of Cashew (Anacardium occidentale L.) Nuts. Botany Research International. 2 (4): 253-257.

Sudripta, D., Timir, B., Jha ., and Sumita, J.,1996. In vitro propagation of cashewnut. Plant Cell Reports. 15:615-619.
Sumita, J., and Sudripta, D., 2005. Tissue Culture of Cashewnut. In.Plant Biotechnology and Molecular Markers.(Eds.) Srivastava.P.S, Alka $\mathrm{N}$ and Sheela.S. Anamaya Publishers, New Delhi, India.pp-244260.

Thimmappaiah., and Shirly, R.S., 1999. In vitro regeneration of cashew (Anacardium occidentale L.) Ind. J. Exp. Biol. 37: 384-390.

Thimmappaiah, Shirly, R.A., and Sadhana, P.H., 2002. In vitro propagation of cashew from young trees.In Vitro Cell. Dev. Biol. Plant. 38: 152-156.

Togun, A., 1977. A review of the prospect of cashew industry.Cocoa Research Institute of Nigeria, pp.100-110.

\section{How to cite this article:}

Sija, S.L., V.P. Potty and P.S. Santhoshlal. 2016. In Vitro Shoot Proliferation from Excised Shoot Tip and Nodal Segment of Anacardium occidentale L. Int.J.Curr.Microbiol.App.Sci. 5(3): 635-642. doi: http://dx.doi.org/10.20546/ijcmas.2016.503.074 